\title{
Long term evaluation of functional and morphological bladder alterations on alloxan-induced diabetes and aging. Experimental study in rats ${ }^{1}$
}

\author{
Avaliação funcional e morfológica tardia de alterações na bexiga secundárias ao \\ diabetes induzido por aloxano e no envelhecimento. Estudo experimental em ratos
}

\begin{abstract}
Antonio Antunes Rodrigues Jr ${ }^{\text {I }}$, Haylton Jorge Suaid ${ }^{\text {II }, ~ S i l v i o ~ T u c c i ~ J r r I I, ~ V a l e ́ r i a ~ P a u l a ~ S a s s o l i ~ F a z a n ~}{ }^{\text {IV }}$, Milton César Foss $^{\text {v }}$, Adauto José Cologna ${ }^{\text {VI }}$, Antonio Carlos Pereira Martins ${ }^{\text {VII }}$

I MD, Fellow PhD degree, Division of Urology, Department of Surgery and Anatomy, Ribeirão Preto Faculty of Medicine, University of São Paulo, Brazil.

II PhD, Associate Professor, Division of Urology, Department of Surgery and Anatomy, Ribeirão Preto Faculty of Medicine, University of São Paulo, Brazil.

III PhD, Associate Professor, Division of Urology, Department of Surgery and Anatomy, Ribeirão Preto Faculty of Medicine, University of São Paulo, Brazil.

Iv MD, PhD, Department of Surgery and Anatomy, Ribeirão Preto Faculty of Medicine, University of São Paulo, Brazil.

v Full Professor and Head, Department of Clínical Médicine, Ribeirão Preto Faculty of Medicine, University of São Paulo, Brazil.

${ }^{v 1} \mathrm{MD}$, PhD, Division of Urology, Departament of Surgery and Anatomy, Ribeirão Preto Faculty of Medicine, University of São Paulo, Brazil.

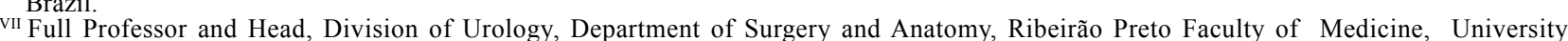
of São Paulo, Brazil.
\end{abstract}

\begin{abstract}
Purpose: to evaluate structural and functional effects of Alloxan- induced diabetes and aging on bladder of rats. Methods: evaluations were performed in three groups: A - 8 weeks of age, B - 44 weeks of age, C - 44 weeks of age with alloxaninduced diabetes. Muscle layer thickness, extracellular matrix fibrosis and collagen were quantified on digital images of bladder samples. Cystometric evaluations before surgical vesical denervation (SVD), included maximum cystometric capacity (MCC), maximum bladder pressure (MBP), bladder contraction frequency (VCF), duration of bladder contraction (DC), threshold pressure (TP) and bladder compliance (BC). After SVD, maximum cystometric capacity (MCC), BC and maximum urethral closing pressure (MUCP) were also measured. Results: Reduced extracellular matrix fibrosis concentration and contraction strength were found in the bladders of group C. Before SVD, bladder compliance was not different between groups. Alterations were observed in MCC after SVD. Conclusions: We did not notice smooth muscle hypertrophy in Alloxan-induced diabetic rats after 44 weeks. There was alteration in the total and relative amount of fibrosis and collagen. The cystometric studies support the idea that this morphological alterations are important to determine the different bladder functional patterns found in the aging and the Alloxan-induced diabetic animals.
\end{abstract}

Key words: Aging. Diabetes. Muscle Layer. Extracellular Matrix. Cystometry. Bladder

\section{RESUMO}

Objetivos: avaliar alterações estruturais e funcionais da bexiga de ratos machos, associadas ao diabetes induzido por aloxano e ao envelhecimento. Métodos: três grupos de animais: A - 8 semanas de idade; B- 44 semanas de idade; C - 44 semanas de idade com diabetes induzido por aloxano, foram avaliados. Realizadas medidas de espessura da camada muscular, fibrose de matriz extracelular e quantidade de colágeno, através de análise de imagem digital dos tecidos. Realizados também testes cistométricos, antes da desnervação vesical cirúrgica (DVC), para avaliar capacidade vesical (CV), intensidade máxima de contração vesical (IMCV) e complacência vesical. Após a DVC, foram avaliadas capacidade vesical após a desnervação (CVAD), complacência vesical (CV) e pressão de perda uretral (PPU). Resultados: não foi observada hipertrofia da camada muscular nas bexigas; houve diminuição da concentração de fibrose da matriz extracelular e diminuição da força contrátil, e aumento da capacidade vesical no grupo C. Conclusões: a atrofia da camadas muscular da bexiga esta relacionada ao diabetes induzido por aloxano. O envelhecimento, como fenômeno isolado, provoca alterações nos parâmetros funcionais, porém associado ao diabetes, gera alterações na IMCV, CV e CVAD. Existe correlação entre alterações estruturais e funcionais nos animais diabéticos após a desnervação.

Descritores: Envelhecimento. Diabetes. Camada Muscular. Matriz Extracelular. Cistometria. Bexiga.

1. Department of Surgery and Anatomy, Ribeirão Preto Faculty of Medicine, University of São Paulo, Brazil. 


\section{Introduction}

In 2025,20 to $25 \%$ of the population will be over 60 years of age in Brazil, and an overload in the public health system is expected. Chronic-degenerative diseases are an issue of concern, and Diabetes Mellitus (DM) is a common disease in this population. ${ }^{1,2}$ Aging and diabetes cause functional and structural alterations in the lower urinary tract. Elderly diabetic patients, though, seem to present a different pattern of urinary dysfunction, which is more than a sum of aging and diabetes.

In aging, experimental studies demonstrated structural alterations such as reduction of the neuronal density, smooth muscle hypertrophy, increase of collagen between the muscle cells and change in the relative amount of collagen type I and $\mathrm{III}^{3}$ Other authors also described alterations in the urethra, like urotelium and submucosal thinning, reduction of proteoglicans and extracellular matrix, and smooth muscle atrophy. ${ }^{4-7}$ Elbadawl et al correlated the morphologic alterations of detrusor smooth muscle to functional changes, such as detrusor hyperactivity, infravesical obstruction and in the impaired detrusor contractility. ${ }^{3}$ Chun et al observed rats up to 24 weeks of age. They noticed functional changes, as a gradual increase of the water intake, diuresis, miccional frequency and urinary volume. All the studies evaluated the animals during short periods of time and the latter, which had the longest followup period, did not perform structural evaluations. Morphologic changes due to aging remain an undefined issue.

As it happens in aging, lower tract dysfunctions are also very frequent in diabetes mellitus (DM). The term diabetic cystopathy was used for the first time in 1976, by Frimodt-Moller. It was defined as a decrease of the vesical sensitivity associated to an increase of the capacity and reduction of contractile response of the detrusor smooth muscle. ${ }^{8}$ Other authors later described the overactive bladder as the most common lower urinary tract dysfunction in diabetic patients. ${ }^{9-12}$ It is also believed that the vesical dysfunction of the diabetic patients correlates with the underlying autonomic neuropathy more than with morphological alterations. Besides all the existent research, a question motivated this study: Is there an overlap between DM and aging effects on the physiopathology of the vesical dysfunction and morphological alterations of the bladder? In the present study we associated cystometric studies with surgical denervation of the bladder to evaluate the importance of the structural alterations in vesical disfunction on aging and Alloxan-induced diabetic rats.

\section{Methods}

Male Wistar rats were divided into three groups: A - 6 animals, with eight weeks of age; B - 5 animals, with 44 weeks of age; C - 10 Alloxan-induced diabetic animals, with 44 weeks of age. Diabetes was induced by intra-peritoneal Alloxan $(40 \mathrm{mg} / \mathrm{kg})$, in the eighth week of age and DM was confirmed through blood glucose testing one week later. The animals of groups B and C were kept under the same environmental conditions, without restriction of food or water. Animals were sedated with Uretan $(1,25 \mathrm{mg} / \mathrm{kg})$ before experimental manipulation. Animals were weighted and submitted to blood sampling for dosage of glycemia. They were then submitted to two surgical procedures: (1) cystostomy - a P50 catheter was introduced in the bladder, fixed with Prolene 5:0 and exteriorized through an opening in the abdominal wall; then urine samples were collected for culture. (2) surgical vesical denervation (SVD) - surgical dissection until the level of the ureteral vesical necks, with visualization of the proximal urethra. The cystotomy catheter was connected in " $y$ " to an infusion pump and to a pressure transducer. Saline was injected at $0,3 \mathrm{ml} / \mathrm{min}$. The variations of vesical pressure were registered in a milimetric paper by a polygraph with $0,05 \mathrm{~mm} / \mathrm{s}$ of speed. The following parameters were registered: maximum cystometric capacity (MCC), maximum bladder pressure (MBP), bladder contraction frequency (BCF), duration of bladder contraction (DC), threshold pressure (TP) used to calculate bladder compliance. After SVD, maximum cystometric capacity (MCC), bladder compliance and maximum urethral closing pressure (MUCP) were also measured. The cystometric registers are illustrated in Figures 1 and 2.

\section{Vesical pressure registration before surgical bladder denervation}

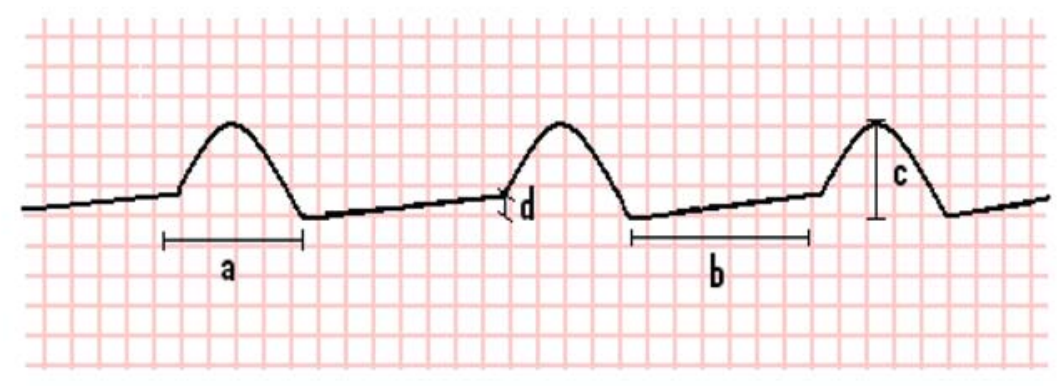

FIGURE 1 - Bladder pressure before surgical vesical denervation. Pressure peaks represent vesical contractions. Other variable are deduced from tracings as shown: (a) duration of contraction; (b) maximum cystometric capacity; (c) maximal bladder pressure; (d) threshold pressure. 


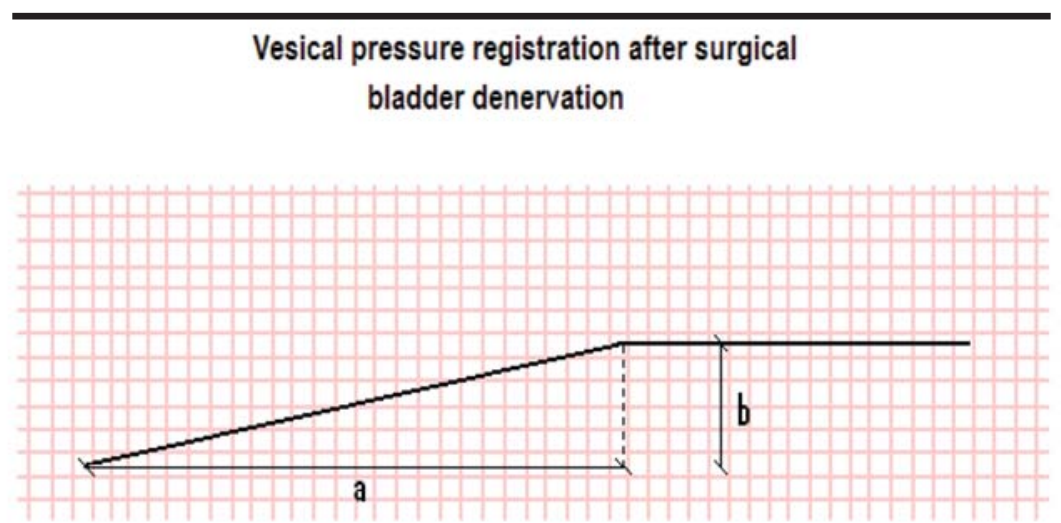

FIGURE 2 - Vesical pressure registration after the SVD. Pressure peaks represent maximal urethral closing pressure (a). The maximum cystometric capacity (b) are deduced from tracings, as shown.

After functional studies, animals were sacrificed. The bladder and urethra were removed and fixed at optimal length in neutral buffer formalin $(10 \%)$ for 24 hours. Formalinfixed, paraffin-embedded tissues were sectioned at $5 \mu \mathrm{m}$ and stained with hematoxylin and eosin (HE), Masson's trichrome (MT) and pricosirius-red (SR), for studies of muscle layer thickness, fibrosis and type I collagen, respectively. The stained sections were analyzed in the the Molecular Biology Laboratory of the Department of Surgery and Anatomy of the FMRP - USP, with a Carl Zeiss-2 Axiskop plus microscope, magnification was 100x. Images were captured through the digital camera Carl Zeiss Axio Cam HR, with image definition of $1300 \times 1030$ pixels. Each pixel corresponds two micrometers. Computer programs 3.1 Axiovision and Adobe Photoshop were used to analyze the digital images. Three consecutive measures in each digital image were done. The thickness of the muscular layer was measured on images of HE. Fibrosis area and total area were measured on images of MT. For the total area measuring, the computer program summed areas from all colors on the image. Total collagen was measured on images of SR. Figure 3 illustrates samples of digital images.

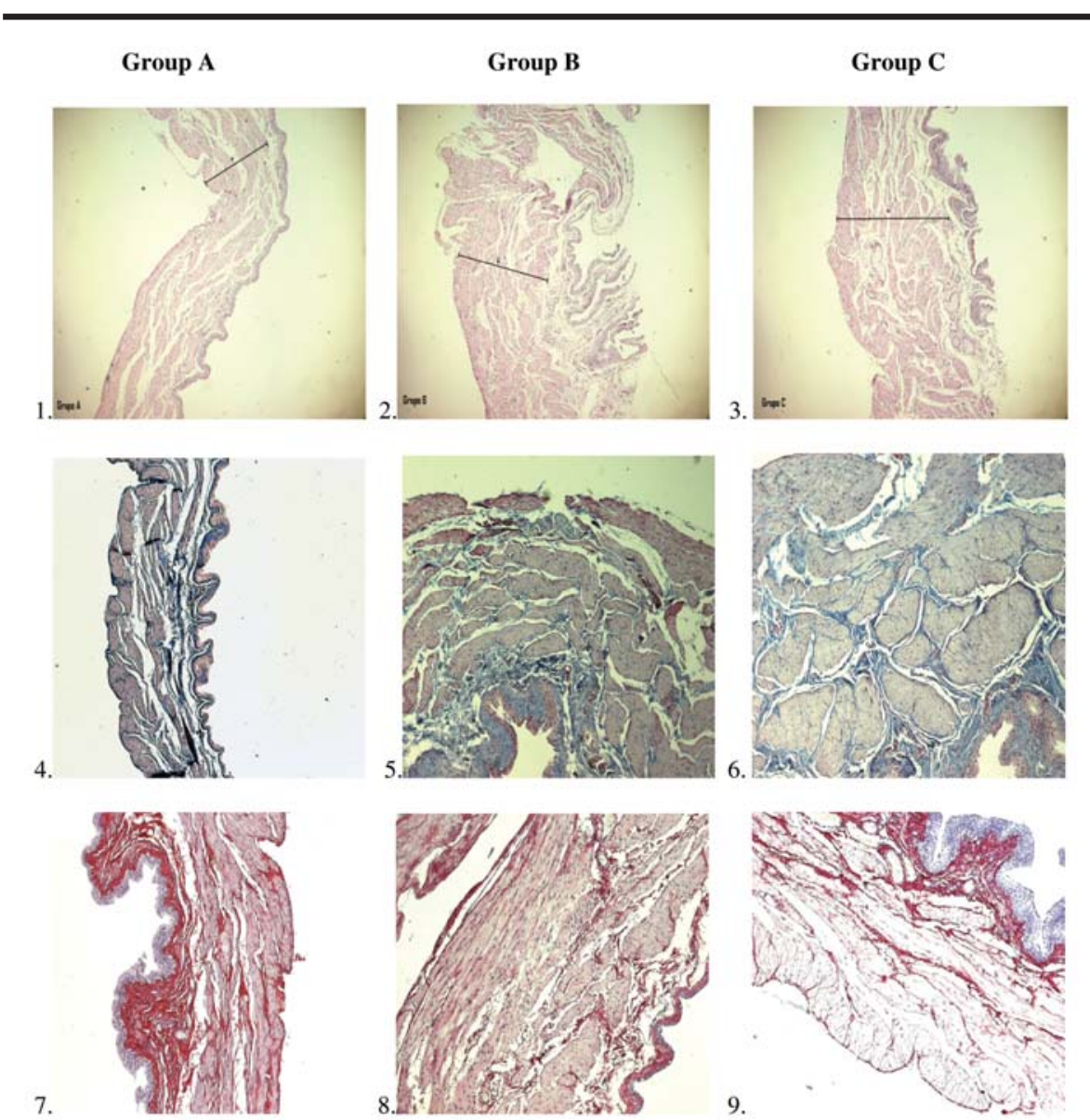

FIGURE 3 - Digital images (100x) from HE (1, 2 and 3), Masson's trichrome (4, 5 and 6 ) and pricosirius-red staining. 
ANOVA was used for statistical analysis in the repeated measures. When there was significant difference $(p<0,05)$ the post hoc test of Bonferroni was used.

\section{Results}

The diabetic animals (group C) presented less weight and greater values of glycemia when compared with the aging animals (group B) (Table 1). All the urinary microbiologic cultures were negative.

\section{Morphological evaluations}

There were no differences between animal groups at total thickness and thickness of muscle layer evaluations. Total fibrosis area was larger in groups $\mathrm{B}$ and $\mathrm{C}(\mathrm{p}<0,007)$; fibrosis area/total area ratio were 28,43 and $36 \%$ for groups $\mathrm{A}, \mathrm{B}$ and $\mathrm{C}$, respectively, without significant difference. The collagen area/fibrosis area ratio of 1,$49 ; 0,69$ and 1,28 respectively were found in groups A, B and C. All mean values and standard errors of these morphological variables are shown in Table 1.

TABLE 1 - Morphometric variables

\begin{tabular}{lcccccccc}
\hline \multirow{2}{*}{ VARIABLES } & \multicolumn{2}{c}{ Group $\boldsymbol{A}$} & \multicolumn{2}{c}{ Group $\boldsymbol{B}$} & \multicolumn{2}{c}{ Group $\boldsymbol{C}$} & \multirow{2}{*}{$\boldsymbol{p}$} \\
\cline { 2 - 7 } & $\boldsymbol{x}$ & $\boldsymbol{S R}$ & $\boldsymbol{x}$ & $\boldsymbol{S R}$ & $\boldsymbol{x}$ & $\boldsymbol{S R}$ & \\
\hline Weight $(\mathrm{g})$ & 207,5 & 25,3 & 696 & 134,5 & 384,3 & 177,6 & $\mathbf{0 , 0 0 0 1}$ \\
Glycemia $(\mathrm{mg} / \mathrm{dl})$ & 138 & 25,84 & 90 & 27,54 & 352,6 & 218,9 & $\mathbf{0 , 0 0 0 1}$ \\
Total thickness $(\mu \mathrm{m})$ & 511,78 & 46,87 & 581,90 & 57,40 & 533,55 & 43,39 & 0,64 & NS \\
Muscle layer thickness $(\mu \mathrm{m})$ & 347,19 & 25,75 & 434,47 & 31,53 & 395,63 & 23,84 & 0,13 & NS \\
Fibrosis area (pixels/mm $\left.{ }^{2}\right)$ & 2,02 & 0,46 & 4,17 & 0,57 & 4,24 & 0,43 & $\mathbf{0 , 0 0 7}$ & \\
Fibrosis area/total area ratio & 28,86 & 3,93 & 43,58 & 4,81 & 36,04 & 3,64 & 0,09 & NS \\
Collagen area/fibrosis area ratio & 149,06 & 22,13 & 69,90 & 27,11 & 128,13 & 20,49 & $\mathbf{0 , 1 1}$ & NS \\
\hline$x-$ mean
\end{tabular}

$\mathrm{x}$ - mean

$\mathrm{SR}$ - standard error

NS - not significant

Functional evaluation

- Maximum cystometric capacity: the diabetic animals had a larger bladder capacity than the other groups, before and after SVD. When bladder capacity was evaluated individually, before and after the DVC, there was significant difference only in the diabetic group.

- Bladder compliance: there was no difference between groups before SVD. After the SVD all groups were different $(p<0,001)$.
- $\quad$ Maximal micturition pressure: group B presented the largest amplitude of contraction. Groups A and $\mathrm{C}$ did not shown significant difference.

- Maximal urethral closing presure: there was no difference between groups.

- Duration of bladder contration: no difference between groups.

- $\quad$ Frequecy: group A had high micturition frequency than others groups.

All mean values and standard error of these functional variables are enumerated in Table 2.

TABLE 2 - Functional variables

\begin{tabular}{|c|c|c|c|c|c|c|c|c|}
\hline \multirow{2}{*}{ VARIABLES } & \multicolumn{2}{|c|}{ Group A } & \multicolumn{2}{|c|}{ Group B } & \multicolumn{2}{|c|}{ Group $C$} & \multirow{2}{*}{$p$} & \\
\hline & $x$ & $S R$ & $x$ & $S R$ & $x$ & $S R$ & & \\
\hline \multicolumn{9}{|l|}{ Bladder capacity } \\
\hline Before SVD (ml) & 0,12 & 0,12 & 0,45 & 0,12 & 0,86 & 0,09 & $<0,001$ & \\
\hline after SVD (ml) & 0,65 & 0,05 & 1,30 & 0,29 & 2,68 & 0,26 & $<0,001$ & \\
\hline \multicolumn{9}{|l|}{ Bladder compliance } \\
\hline Before SVD (ml/mmHg) & 0.04 & 0,06 & 0,05 & 0,06 & 0,21 & 0,05 & 0,07 & NS \\
\hline after SVD (ml/mmHg) & 0,12 & 0,10 & 0,47 & 0,11 & 0,81 & 0,08 & $<0,001$ & \\
\hline Maximal bladder pressure $(\mathrm{mmHg})$ & 28,83 & 5,30 & 48,56 & 5,80 & 32,40 & 4,32 & 0,05 & \\
\hline $\begin{array}{l}\text { Maximal urethral closing pressure } \\
(\mathrm{mmHg})\end{array}$ & 21,50 & 3,40 & 31,73 & 3,64 & 24,24 & 3,68 & 0,72 & NS \\
\hline Frequency (contractions/min) & 9,40 & 0,87 & 3,33 & 0,65 & 6,04 & 1,08 & 0,003 & \\
\hline Duration of bladder contraction & 23,33 & 2,85 & 14,60 & 3,12 & 19,11 & 2,33 & 0,15 & NS \\
\hline Threshold pressure & 4,66 & 2,31 & 14,54 & 2,53 & 7,61 & 1,88 & $\mathbf{0 , 0 3}$ & \\
\hline
\end{tabular}




\section{Discussion}

In the present study, we observed higher levels of serum glucose and important weight loss in diabetic animals. It confirms the success of the experimental model with Alloxan-induced diabetes. ${ }^{13-18}$ Morphological alterations of the detrusor smooth muscle were described previously in induced diabetes and aging experimental models. However, previous mentioning of delayed alterations of the detrusor smooth muscle does not exist in the literature. ${ }^{15-22}$ We did not observe differences in total thickness and muscle layer thickness in bladders, but we noticed a higher fibrosis area in the diabetic and in the aging animals, suggesting that there is relative atrophy of bladder muscle layer.

Literature describes an increase in the absolute amount and a reduction of the relative concentration of collagen, mainly of collagens type I and III, in bladders of the diabetic and the aging animals, in short periods of observation. ${ }^{15-23}$ The findings of our study suggest that the relative amount of collagen and the ratio of collagen I and III are different in the diabetic and the aging animals after long term observation. ${ }^{15-23}$ That is supported by the functional alterations observed in this study. It is known that collagen III is related to low compliance in aging bladders. And it is also known that in aging animals and in humans there is a change in the ratio between collagens type I and III, with an increase in the amount of collagen type III. ${ }^{23}$ We noticed high bladder compliance values in diabetic animals, mainly after denervation. The finding suggests that there might be a protective factor in diabetic animals, perhaps a different ratio of collagen I and III than in the aging animals.

Bladder capacity measures were elevated in the diabetic rats as had been reported in shorter periods of observation. ${ }^{18,19}$ In aging animals, however, we did not notice alterations in bladder capacity and compliance before and after denervation. It suggests that the amount of fibrosis and the ratio between collagens type I and III are important factors to determine this functional pattern instead of possible neurological alterations.

The high frequency of bladder contraction in the young animals could be related with a high susceptibility of these animals to bladder irritation secondary to the cystostomy catheter. ${ }^{12,17}$

\section{Conclusion}

We did not notice smooth muscle hypertrophy in Alloxan-induced diabetic rats after 44 weeks. There was alteration in the total and relative amount of fibrosis and collagen. The cystometric studies support the idea that this morphological alterations are important to determine the different bladder functional patterns found in the aging and the Alloxan-induced diabetic animals.

\section{References}

1. Veras RP, Ramos LR, Kalache A. Crescimento da população idosa no Brasil: transformações e conseqüências na sociedade. Rev Saúde Pública. 1987;21:225-33.

2. Chaimowicz F. A saúde dos idosos brasileiros às vésperas do século XXI: problemas, projeções e alternativas. Rev Saúde Pública. 1997;31:184-200.

3. Elbadawi A, Yalla SV, Resnik NM. Structural basis of geriatric voiding dysfunction. Methods of a prospective ultrastructural/urodynamic study and an overview of findings. J Urol. 1993;150:1650-7.

4. Carlile A, Davies I, Rigby A, Brocklehurst JC. Age changes in the human female urethra a morphometric study. J Urol. 1988;139:532-5.

5. Forsberg JG. A morphologist's approach to the vagina - age related changes and estrogen sensitivity. Maturitas. 1995;22:S7-15.

6. Verelst M, Maltau JM, Orbo A. Computerised morphometric study of the paraurethral tissue in young and elderly women. Neurourol Urodyn. 2002;21:529-33.

7. Perucchini D, DeLancey JO, Ashton-Miller JA, Galecki A, Schaer GN. Age effects on urethral striated muscle. II. Anatomic location of muscle loss. Am J Obstet Gynecol. 2002;186:356-60.

8. Frimodt-Moller C. Diabetes cystopathy: I. A clinical study on the frequency of bladder dysfunction in diabetes. Dan Med Bull. 1976;23:267-72.

9. Starer P, Libow L. Cystometric evaluation of bladder dysfunction in elderly diabetic patients. Arch Inter med. 1990;150:810-3.

10. Kaplan SA, Te AE, Blaivas JG. Urodynamic findings in patients with diabetic cystopathy. J Urol. 1995;152:342-4.

11. Elbadawi A, Diokono AC, Millard RJ. The aging bladder: morphology and urodynamics. World J Urol. 1998;16:10-34.

12. Chun AL, Wallace LJ, Gerald MC, Levin RM, Wein AJ. Effect of age on in vivo urinary bladder function in the rat. J Urol. 1993;139:625-7.

13. Eika B, Levin RM, Longhurst PA. Comparison of urinary bladder function in rats with hereditary diabetes insipidus, streptozotocininduceddiabetes mellitus, and nondiabetic osmotic diuresis. J Urol. 1994;151:496-502.

14. Longhurst PA, Levenducky MC, Bezuijen MWF. Diabetes mellitus increases the rate of development of decompesation in rats with outlet obstruction. $\mathrm{J}$ Urol. 2004;171:933-7.

15. Poladia DP, Bauer JA. Functional, Structural, and Neuronal Alterations in Urinary Bladder during Diabetes: Investigations of a Mouse Model. Pharmacology. 2005;74:84-94.

16. Uvelius B. Detrusor smooth muscle in rats with alloxan-induced diabetes. J Urol. 1986;136,949-52.

17. Andersson PO, Malmgren A, Uvelius B. Cystometrical and in vitro evaluation of urinary bladder function in rats with streptozotocininduced diabetes. J Urol. 1988;139:1359-62.

18. Malmgren A, Andersson PO, Uvelius B. Bladder function in rats with short- and long-term diabetes; 
effects of age and muscarinic blockade. J Urol. 1989;142:1608-14.

19. Brown JS, Wessels H, Chancellor MB, et al. Urologic complications of diabetes. Diabetes Care. 2005;28:177-83.

20. Lincon J, Haven A, Sawyer M, Burnstock G. The smooth muscle of rat bladder in the early stages of streptozotocin-induced diabetes. British J Urol. 1984;56:24-7.

21. Pitre DA, Wallace LJ, Bauer JA. Time-dependent urinary bladder remodeling in the streptozotocininduced diabetic rat model. Acta Diabetol. 2002;39:23-7.
22. Karam I, Moudouni S, Droupy S, Abd-Alsamad I, Uhl JF, Delmas V. The structure and innervation of the male urethra: histological and immunohistochemical studies with tridimensional reconstruction. J Anat. 2005;206:395-403.

23. Macarak EJ, Howard PS. The colagens and their urologic significance. Scand J Urol. 1997;184:2533.

\section{Correspondence:}

Antonio Antunes Rodrigues Jr

Department of Surgery and Anatomy

Ribeirão Preto Faculty of Medicine, University of São Paulo

Av. Bandeirantes 3900,

14048-900 Ribeirão Preto, SP, Brazil

Phone/Fax: (+55) 16 3602-2593

aantunesrj@yahoo.com.br

Conflict of interest: none Financial source: none

\section{How to cite this article:}

Rodrigues AA Jr, Suaid HJ, Tucci S Jr, Fazan VPS, Foss Mc, Martins ACP. Long term evaluation of functional and morphological bladder alterations on alloxan-induced diabetes and aging. Experimental study in rats. Acta Cir Bras [serial on the Internet], 2008; 23 Suppl 1. Available from URL: http://www.scielo.br/acb.

\section{Comments:}

The authors describe a study in order to evaluate functional and morphological bladder alterations caused by diabetes and aging in animal models. Functional evaluations were done by urodymic studies and morphological analyses by histology (hematoxylin and eosin, Masson's trichrome, and pricosirius red). Diabetics animals showed a larger bladder capacity than other animals and in the older animals, the largest amplitude of contraction.was found . Morphological analyses did not show any significant difference. The data support the idea that functional alterations are responsible for bladder dysfunctions in diabetes and aging and new studies must be done to complete elucidate the mechanisms involved.

\section{Carlos Gilberto Carlotti Jr}

PhD, Associate Professor, Division of Neurosurgery, Department of Surgery and Anatomy, Ribeirão Preto Faculty of Medicine, University of São Paulo, Brazil

\section{Comments:}

Experimental studies that contribute to the understanding of the functional and morphological alterations of the urinary tract that are usually seen in diabetic patients and the elderly are extremely valuable and interesting. Three groups of animals were used by the authors in this study: a normal group of animals, 8 weeks old, a group free of diabetes, 44 weeks old and a third group, 44 weeks old, which had alloxan-induced diabetes when 8 weeks old, before and after bladder denervation. It was considered necessary to verify if there was vesicle lesion superposition in diabetes and old age. For functional studies intravesicle measurements were made through cystostomy and after denervation the measurements were repeated. After sacrifice of the animals, vesicle tissue was evaluated by muscle layer thickness, presence of fibrosis and of type I collagen. Diabetic rats showed an atrophic bladder muscular layer Aging, per se, induced alterations in functional parameters, but when associated to diabetes additional bladder alterations were also seen. Bladder functional studies suggest that morphological alterations like the amount of fibrosis are important for the choice of functional models between elderly or diabetic rats. According to the authors the experiment showed that relations between types I and III collagen are probably more important than neurologic alterations.

As expected, there was a correlation between structural and functional alterations in diabetic rats after denervation. However, in the long run neurological alterations could turn out to be more important.

\section{Miguel Moyses Neto}

MD, PhD, Division of Nephrology, Department of Clinical Medicine, Ribeirão Preto faculty of Medicine, University of São Paulo, Brazil. 